\title{
Enhanced Biodegradation of Mobil Oil Hydrocarbons by Biosurfactant Producing Bacterial Consortium in Wheat and Mustard Rhizosphere
}

\section{Rajesh Kumar $^{1 *}$, Ram Naresh Bharagava ${ }^{1}$, Manish Kumar', Sanjeev K Singh ${ }^{2}$ and Govind K ${ }^{3}$}

${ }^{1}$ Department of Environmental Microbiology, School for Environmental Sciences, Babasaheb Bhimrao Ambedkar University, Vidya Vihar, Rae Bareli Road, Lucknow, Uttar Pradesh, India

${ }^{2}$ Division of Eco-Restoration, National Environmental Engineering Research Institute, Nehru Marg, Nagpur, India

${ }^{3}$ Department of Microbiology, College of Basic Science and Humanities, Pantnagar, Uttarakhand, India

\begin{abstract}
Hydrocarbon fuels are one of the most common global environmental pollutants which cannot be easily degraded owing to their hydrophobic nature. The present study involves the degradation of hydrocarbons by biosurfactant producing bacterial consortia In this study, results showed $73.66 \%$ and $75.80 \%$ degradation of $2 \%$ mobil oil hydrocarbons in contaminated soil by biosurfactant producing bacterial consortium with wheat (Triticum aestivum) and mustard (Brassica juncea) crops, respectively. Therefore, it indicates that the developed bacterial consortium are capable for the effective degradation of mobil oil hydrocarbons in wheat and mustard rhizosphere and hence can be employed effectively for the degradation of mobil oil hydrocarbons in oil contaminated soils. Phthalate esters formed during the degradation can be used for industrial applications like PVC softening.
\end{abstract}

Keywords: Phthalate esters; Bioremediation; Biosurfactants; Hydrocarbon degradation; Fluorescent pseudomonas

\section{Introduction}

Hydrocarbons are the hydrophobic organic chemicals having toxicity, persistence and negative influence on living organisms and account for $90-95 \%$ or more of the total contaminant mass, exhibit limited solubility in groundwater and tend to partition to the soil matrix [1]. The soil pollution by hydrocarbons like mobil oil is mainly responsible for the changes in physical and chemical properties of soils which result in adverse effects on plant growth parameters $[2,3]$. Moreover, bioremediation is an efficient, economic and versatile alternative to the physico-chemical treatment methods mainly with bacterial consortia or individually $[4,5]$. This bioremediation process of hydrocarbon removal occurs through two distinct, but interrelated processes of biodegradation and microbial uptake, which enhance the hydrocarbon degradation by increasing the substrate bioavailability and by increasing the hydrophobicity of surfaces, by mobilization, solubilization or emulsification [6-8].

Biodegradation is a "microbially driven chemical transformation of organic compounds" [9] whereas microbial uptake is the direct removal of contaminants by adsorbing the compounds onto membrane surface or absorbing compounds through cell membrane. Many microbial species including fluorescent pseudomonads are reported to excrete a variety of totally or partially extracellular, amphipathic biosurfactant molecules that reduces surface tension and facilitates the uptake of hydrocarbons $[10,11]$ and can be employed for the biodegradation and removal of mobil oil hydrocarbons from contaminated soil [1]. However, fluorescent pseudomonad (gram-negative, non-spore forming, motile, rod shaped and versatile bacteria) have been reported to promote plant growth in rhizosphere either directly by producing plant growth regulators and by increasing the plant uptake of some micro and macro elements from the rhizosphere $[12,13]$ or indirectly through biological control of pathogens or induction of host defense mechanisms [14]. This Plant Growth Promoting Rhizobacteria (PGPR) contributes in lowering the abiotic stresses on plants and therefore considered to be an important tool for the phytoremediation technology $[3,15]$.

In this study, a consortium containing fluorescent pseudomonads and Bacillus sp. was developed and used for the degradation and removal of mobil oil hydrocarbons from soil planted with wheat
(Triticum aestivum var. 2565) and mustard (Brassica juncea var. Kranti) plants.

\section{Materials and Methods}

\section{Collection of hydrocarbon contaminated soil/sludge samples}

The soil/sludge samples were collected from the different oil contaminated sites: Haldia $\left(22^{\circ} 03^{\prime} 37.65^{\prime \prime} \mathrm{N}\right.$ latitude and $88^{\circ} 06^{\prime} 35.09^{\prime \prime} \mathrm{E}$ longitude), Jhansi $\left(22^{\circ} 26^{\prime} 38.84^{\prime \prime} \mathrm{N}\right.$ latitude and $78^{\circ} 34^{\prime} 03.37^{\prime \prime} \mathrm{E}$ longitude) and Pantnagar $\left(29^{\circ} 01^{\prime} 20^{\prime \prime} \mathrm{N}\right.$ latitude and $79^{\circ} 29^{\prime} 15^{\prime \prime} \mathrm{E}$ longitude), India. These soil/sludge samples were used for the isolation of plant growth promotory and biosurfactants producing bacterial strains.

Isolation and characterization of plant growth promoting and biosurfactant producing bacterial strains

The test strains were isolated from soil/sludge samples collected from different sites by serial dilution method on King's B agar media at $30^{\circ} \mathrm{C}$ in 48 hours. These isolated test strains were characterized morphologically, biochemically as per the standard procedures [16] and for plant growth promoting properties such as siderophore [17], ammonia, indole acetic acid [18], HCN production [19] and phosphate solubilization [20]. In addition, the test strains were also screened for biosurfactant production on Mineral Salt Medium (composition in $\mathrm{g} / \mathrm{l}$, $\mathrm{NaNO}_{3} 2.5 ; \mathrm{K}_{2} \mathrm{HPO}_{4} 1.0 ; \mathrm{KH}_{2} \mathrm{PO}_{4} 0.5 ; \mathrm{MgSO}_{4}$ (anhydrous) $0.5 ; \mathrm{KCl} 0.1 ;$ $\mathrm{FeSO}_{4}$ 0.01; $\mathrm{CaCl}_{2}$ 0.01; $\mathrm{Na}_{2} \mathrm{HPO}_{4} 5.67 ; \mathrm{MnSO}_{4} 0.002 ; \mathrm{NH}_{4} \mathrm{NO}_{3} 0.39$ and dextrose 30 ). The $\mathrm{pH}$ of medium was maintained at 7.0, followed

*Corresponding author: Rajesh Kumar, Department of Environmental Microbiology, School for Environmental Sciences, Babasaheb Bhimrao Ambedkar University, Vidya Vihar, Rae Bareli Road, Lucknow, Uttar Pradesh, India, E-mail: rajesh4971@yahoo.com

Received September 23, 2013; Accepted October 21, 2013; Published October 28,2013

Citation: Kumar R, Bharagava RN, Kumar M, Singh SK, Govind K (2013) Enhanced Biodegradation of Mobil Oil Hydrocarbons by Biosurfactant Producing Bacterial Consortium in Wheat and Mustard Rhizosphere. J Pet Environ Biotechno 4: 158. doi:10.4172/2157-7463.1000158

Copyright: ( 2013 Kumar R, et al. This is an open-access article distributed unde the terms of the Creative Commons Attribution License, which permits unrestricted use, distribution, and reproduction in any medium, provided the original author and source are credited. 
Citation: Kumar R, Bharagava RN, Kumar M, Singh SK, Govind K (2013) Enhanced Biodegradation of Mobil Oil Hydrocarbons by Biosurfactant Producing Bacterial Consortium in Wheat and Mustard Rhizosphere. J Pet Environ Biotechnol 4: 158. doi:10.4172/2157-7463.1000158

Page 2 of 8

by incubation at $30^{\circ} \mathrm{C}$ for 48 hours under shaking flask condition at $150 \mathrm{rpm}$ on a rotary shaker. The promising test strains for the above properties were characterized molecularly on the basis of $16 \mathrm{~S}$ rRNA gene sequence analysis and the phylogenetic tree was constructed by blasting the data (FASTA format) using the software Mega4 to know the relatedness between the isolated test strains.

\section{Bioassay for biosurfactant production and its characterization by FTIR analysis}

The biosurfactants produced by the test strains on Mineral Salt Medium were characterized on the basis of different properties viz; foaming, surface tension (after centrifugation at 10,000 rpm for 20 minutes) by De Nuoy Ring Detachment Method [21], emulsification index [22], drop collapse test and haemolytic activity. The biosurfactants were extracted by diethyl ether extraction method. Seventy two hours grown test cultures on Mineral Salt medium at $30^{\circ} \mathrm{C}$ under shaking flask conditions at $150 \mathrm{rpm}$ were centrifuged at $10,000 \mathrm{rpm}$ for 20 minutes at $4^{\circ} \mathrm{C}, \mathrm{pH}$ of the supernatant was adjusted to 2.0 with $6 \mathrm{~N} \mathrm{HCl}$ and allowed to stand overnight at room temperature. The biosurfactant was extracted with 2 volumes of diethyl ether in a separating funnel with vigorous shaking for 60 minutes on a shaker. The upper organic layer was collected and transferred to pre-weighed dry beakers. Diethyl ether was allowed to evaporate for 24 hours and the samples were dried in an oven at $60^{\circ} \mathrm{C}$ for one hour, light brown coloured biosurfactant obtained was subjected to FTIR analysis. The samples were grounded with $\mathrm{KBr}$ in the ratio of 100:1 (100 $\mathrm{mg} \mathrm{KBr}$ and $1 \mathrm{mg}$ sample) in an agate motor to make the pellets by using a Hydraulic press (CAP 15T) at a pressure of ten tons. Finally, the grinded samples were analysed by using FTIR (Bruker, Vertex 70)

\section{Development of hydrocarbon emulsifying and plant growth promoting bacterial consortia}

The promising hydrocarbon emulsifying and plant growth promoting bacterial strains were selected to develop consortia on the basis of compatibility studies. By using agar diffusion technique on King's B solid medium, strains were studied for compatibility. Those showing compatibility were selected for making consortia. The developed consortia were again checked for compatibility in liquid media (50 ml MSM broth) in presence and absence of hydrocarbons (mobil oil 2\%). The absorbance was taken at periodic interval of 24 hours from 0 hours upto 120 hours in spectrophotometer (Beckman DU $340 \mathrm{~B}$ model) and finally, based on growth pattern, three consortia, C1 (H1A, H1B, H1C), C2 (J2A, P2A, J1A) and C3 (J1A, J1B, H1C) were selected for the in situ bioremediation of mobil oil hydrocarbons in wheat (Triticum aestivum) and mustard (Brassica juncea) rhizosphere.

\section{Pot experiment}

The experimental soil was mixed, allowed to dry to get water content less than $1 \%$, sieved with $2 \mathrm{~mm}$ sieve and autoclaved at $121^{\circ} \mathrm{C}$ for $1 \mathrm{hr}$ for three consecutive days. From this autoclaved soil, $1.5 \mathrm{~kg}$ of soil was transferred to each pot and mixed with $30 \mathrm{~g}(2 \%)$ of mobil oil hydrocarbons. Different consortia were added to the experimental pots (50 ml i.e. $\sim 1 \times 10^{7}$ cells $\left.\mathrm{ml}^{-1}\right)$. Suitable controls without hydrocarbons and/or bacterial consortia were kept as control. Surface sterilized seeds of wheat (Triticum aestivum) and mustard (Brassica juncea) were sown at a depth of $2.5 \mathrm{~cm}$. The pots were kept under observation for germination (seedling germination percentage) and plant health parameters (i.e. seedling survival, average plant height, chlorophyll content using Spadmeter optisciences 2000, plant biomass, average shoot height, average stem dry weight with fruit, average seed weight, average root weight and average yield per pot). The data obtained was analysed using statistical software. This experiment was carried out for 120 days in poly house at room temperature.

\section{Characterization of residual hydrocarbons}

Extraction of residual hydrocarbons from wheat and mustard rhizosphere: Approximately $5 \mathrm{~g}$ of soil sample from mobil oil contaminated soil was taken initially ( 0 days, control) and after cultivation of wheat and mustard at 120 days. To these soil samples, $15 \mathrm{ml}$ of acetone was added followed by $1 \mathrm{hr}$ shaking and the residue obtained was filtered and washed again twice with acetone, followed by filtration and concentration on a rotatory vaccum evaporator at $50^{\circ} \mathrm{C}$ and analyzed for the presence of residual hydrocarbons using FTIR. 2.6.2 Gas Chromatography Mass Spectrophotometry (GCMS) analysis of extracted residual hydrocarbonsFor GC-MS analysis, the concentrated samples were dissolved in $1 \mathrm{ml}$ of hexane. The quantification of hydrocarbon compound was done by high resolution gas chromatography using QP-2010 gas chromatograph (Shimadzu) equipped with a HP-DB $5 \mathrm{MS}$ column $(60 \mathrm{~m} \times 0.25 \mathrm{~mm}, 0.25 \mu \mathrm{m}$ film thickness) coupled with mass spectrometer detector (HP 5972).

\section{Results and Discussion}

\section{Characteristics of biosurfactant producing plant growth promotory bacterial strains}

In this study, initially, twenty three bacterial strains were isolated, out of which, seven compatible and promising strains for biosurfactant production and plant growth promotory properties were selected for further studies. The test strains $\mathrm{H} 1 \mathrm{~A}, \mathrm{H} 1 \mathrm{~B}$ and $\mathrm{H} 1 \mathrm{C}$ were isolated from oily sludge samples collected from Haldia; J1A, J1B from sludge samples and J2A from oily soil samples collected from Jhansi while test strain P2A from soil of Pantnagar Industrial area.

The morphological and biochemical characteristics of the isolated bacterial strains are represented in Table 1 . All the test strains were found rod shaped and Gram negative except J2A, which was Gram positive and resembled Lysinibacillus sphaericus. Further, the molecular analysis of these bacterial strains showed that most of them belongs to genus Pseudomonas (homology 97-99\%), only one bacterial strain (J2A) belongs to genus Bacillus (Figure 1). In addition, the 16S rRNA nucleotide sequences obtained from test strains were also submitted to gene bank and accession number allotted were JX100389, JX149542, JX149543, JX100388, JX149548, JX149545 and JX149546 for the isolated test strains $\mathrm{H} 1 \mathrm{~A}, \mathrm{H} 1 \mathrm{~B}, \mathrm{H} 1 \mathrm{C}, \mathrm{J} 1 \mathrm{~A}, \mathrm{~J} 1 \mathrm{~B}, \mathrm{~J} 2 \mathrm{~A}$ and $\mathrm{P} 2 \mathrm{~A}$, respectively.

The selected test strains showed various plant growth promotory properties such as siderophore, indole acetic acid, ammonia production, phosphate solubilization, HCN production as shown in Table 2. The isolated test strains were categorized as excellent $(++++)$, good $(+++)$, fair $(++)$, poor $(+)$ based on zone size/optical density measurements amongst the test strains. On the basis of these plant growth promotory properties, it is evident that the isolated strains were capable to solubilize phosphate and sequester iron from soil and provide to plant cell under stress conditions. Moreover, our results are also supported by similar findings as reported by various authors $[23,15]$. Further, out of these isolated bacterial strains, the Indole Acetic Acid (IAA) production was best shown by the strains H1A and J1A that can enhance the various stages of plant growth $[3,24]$

\section{Characteristics of biosurfactant produced by isolated test strains}

Biosurfactant production and result of its various properties are 
Citation: Kumar R, Bharagava RN, Kumar M, Singh SK, Govind K (2013) Enhanced Biodegradation of Mobil Oil Hydrocarbons by Biosurfactant Producing Bacterial Consortium in Wheat and Mustard Rhizosphere. J Pet Environ Biotechnol 4: 158. doi:10.4172/2157-7463.1000158

Page 3 of 8

\begin{tabular}{|c|c|c|c|c|c|c|c|c|}
\hline \multirow{2}{*}{ Sr No. } & \multirow{2}{*}{ Characteristics } & \multicolumn{7}{|c|}{ Test Strains } \\
\hline & & H1A & H1B & $\mathrm{H} 1 \mathrm{C}$ & J1A & J1B & J2A & P2A \\
\hline 1 & Gram reaction & $-v e$ & $-v e$ & -ve & -ve & -ve & $+\mathrm{ve}$ & -ve \\
\hline 2 & $\begin{array}{c}\text { Chromogenesis on King's B } \\
\text { agar }\end{array}$ & Green fluorescence & $\begin{array}{c}\text { Green } \\
\text { fluorescence }\end{array}$ & $\begin{array}{c}\text { Green } \\
\text { fluorescence }\end{array}$ & $\begin{array}{c}\text { Green } \\
\text { fluorescence }\end{array}$ & $\begin{array}{c}\text { Green } \\
\text { fluorescence }\end{array}$ & $\begin{array}{l}\text { Pale Green } \\
\text { fluorescence }\end{array}$ & $\begin{array}{c}\text { Green } \\
\text { fluorescence }\end{array}$ \\
\hline 3 & Oxidase test & $+v e$ & $+\mathrm{ve}$ & + ve & $+\mathrm{ve}$ & + ve & $+\mathrm{ve}$ & $+\mathrm{ve}$ \\
\hline 4 & Catalase test & $+\mathrm{ve}$ & $+\mathrm{ve}$ & $+\mathrm{ve}$ & $+\mathrm{ve}$ & $+\mathrm{ve}$ & $+\mathrm{ve}$ & $+v e$ \\
\hline 5 & Gelatin liquefaction & $+\mathrm{ve}$ & $+\mathrm{ve}$ & $+\mathrm{ve}$ & $+\mathrm{ve}$ & $+\mathrm{ve}$ & $+\mathrm{ve}$ & $+\mathrm{ve}$ \\
\hline 6 & Starch hydrolysis & $+\mathrm{ve}$ & $+\mathrm{ve}$ & $+\mathrm{ve}$ & -ve & $-v e$ & $+\mathrm{ve}$ & $+\mathrm{ve}$ \\
\hline 7 & Casein hydrolysis & $+v e$ & $+\mathrm{ve}$ & $+\mathrm{ve}$ & $+v e$ & $+\mathrm{ve}$ & $+\mathrm{ve}$ & $+\mathrm{ve}$ \\
\hline 8 & Indole & -ve & $-v e$ & $-v e$ & $-v e$ & $-v e$ & $+\mathrm{ve}$ & -ve \\
\hline 9 & Methyl red & -ve & $-v e$ & -ve & $-v e$ & $-v e$ & $-v e$ & $-v e$ \\
\hline 10 & Vogus Prausker & -ve & -ve & -ve & -ve & -ve & -ve & -ve \\
\hline 11 & Citrate utilization test & $+\mathrm{ve}$ & $+\mathrm{ve}$ & + ve & $+\mathrm{ve}$ & -ve & $+v e$ & $+\mathrm{ve}$ \\
\hline
\end{tabular}

Table 1: Morphological and biochemical characteristics of the test strains.

\begin{tabular}{|c|c|c|c|c|c|}
\hline Test Strains & Siderophore Production & IAA Production & $\mathrm{NH}_{3}$ Production & $\mathrm{PO}_{4}^{2-}$ Solubilization & HCN Production \\
\hline $\mathrm{H} 1 \mathrm{~A}$ & ++++ & +++ & +++ & +++ & +++ \\
\hline $\mathrm{H} 1 \mathrm{~B}$ & ++ & ++ & ++ & +++ & +++ \\
\hline $\mathrm{H} 1 \mathrm{C}$ & +++ & ++ & ++ & +++ & +++ \\
\hline $\mathrm{J} 1 \mathrm{~A}$ & ++++ & +++ & +++ & ++++ & +++ \\
\hline J1B & +++ & ++ & +++ & +++ & +++ \\
\hline $\mathrm{J} 2 \mathrm{~A}$ & ++ & + & _- & + & _ \\
\hline $\mathrm{P} 2 \mathrm{~A}$ & +++ & ++ & ++ & +++ & +++ \\
\hline
\end{tabular}

$(++++)$ excellent, $(+++)$ good, $(++)$ fair, $(+)$ poor.

Table 2: Plant Growth Promotory Properties of the isolated bacterial test strains.

\begin{tabular}{|c|c|c|c|c|c|}
\hline \multirow[b]{2}{*}{ Test strains } & \multicolumn{5}{|c|}{ Properties of biosurfactants } \\
\hline & Foaming & Emulsification index $\left(E_{24}\right)$ & $\begin{array}{l}\text { Drop collapse test (+ indicates } \\
\text { surfactant production) }\end{array}$ & Type of hemolysis & Biosurfactant yield $\left(\mathrm{g} \mathrm{l}^{-1}\right)$ \\
\hline $\mathrm{H} 1 \mathrm{~A}$ & + & $2.95 \pm 0.004$ & + & $\beta$-hemolysis & $1.2 \pm 0.049$ \\
\hline H1B & + & $2.94 \pm 0.036$ & + & $\beta$-hemolysis & $1.4 \pm 0.081$ \\
\hline $\mathrm{H} 1 \mathrm{C}$ & + & $8.83 \pm 0.020$ & + & $\beta$-hemolysis & $2.6 \pm 0.067$ \\
\hline J1A & + & $7.65 \pm 0.044$ & + & $\beta$-hemolysis & $1.0 \pm 0.098$ \\
\hline J1B & + & $8.23 \pm 0.004$ & + & $\beta$-hemolysis & $3.6 \pm 0.026$ \\
\hline $\mathrm{J} 2 \mathrm{~A}$ & + & $30.59 \pm 0.012$ & + & a-hemolysis & $1.6 \pm 0.077$ \\
\hline $\mathrm{P} 2 \mathrm{~A}$ & + & $11.18 \pm 0.032$ & + & $\beta$-hemolysis & $2.0 \pm 0.044$ \\
\hline
\end{tabular}

Table 3: Biosurfactant properties of the test strains.

summarized in Table 3. All the test strains were found to produce foam in the mineral salt medium. There was a reduction in the surface tension by the test strain surfactants (Figures $2 \mathrm{a}-2 \mathrm{e}$ ). Surface tension measured by tensiometer at different time intervals $(0,24,48,72,96$ and $120 \mathrm{~h}$ ) of 7 test strains in MSM broth showed that H1A, H1B, and H1C reduced surface tension from 72.8 to $25.13,25.71$ and 25.1 dynes $\mathrm{cm}^{-1}$, respectively and other test strains J1A, J1B, J2A and P2A reduced surface tension from 72.8 to $26-29$ dynes $\mathrm{cm}^{-1}$. Growth pattern also showed an increase upto 72 hours of incubation period in all the cases, beyond which the growth stabilised as measured by the turbidity in MSM broth. However, in case of test strains H1A and H1B, there was a decline in the growth phase beyond 72 hours (Figures 2a-2e).

The mobil oil hydrocarbons emulsification by the biosurfactants varied from 30.59 (J2A) to 2.94 (H1B) as shown in Table 3. All the test isolate were found positive for drop collapse test (drop collapsed after spreading). In addition, beta and alpha haemolysis were shown by surfactants with $\mathrm{J} 2 \mathrm{~A}$ surfactant showing alpha haemolysis while surfactants produced by other strains showed beta haemolysis. Biosurfactant yield using diethyl ether method ranged from 1.0 (Strain J1A) to 3.6 (Strain J1B) $\mathrm{g} \mathrm{l}^{-1}$. Further, the biosurfactants were characterized by using FTIR analysis.

\section{FTIR analysis of biosurfactant produced by the test strains}

The IR spectra of biosurfactants produced by all the test strains showed the presence of different bonds as shown in (Figures 3a$3 g)$. However, there are certain bonds which are common like $-\mathrm{CH}_{2}$ stretching frequency from 2848 (H1B) to 2927 (P2A), C-C stretching vibration (1045-1147) and $\mathrm{C}-\mathrm{H}$ deformation frequency (1378-1461). Moreover, the biosurfactant from the test strain J1B did not show $\mathrm{C}-\mathrm{H}$ deformation frequency. Further, P-H bonding (2356-2372) is shown by H1A, H1C and P2A only, while secondary amide (3359) by J1A and P2A. The differences in the peaks can be used for differentitating the biosurfactants produced by the test strains as well as a marker for identifying the biosurfactants.

\section{Effect of developed bacterial consortium on seed germination and plant growth parameters.}

In the present study, seed germination was recorded as 80 and $60 \%$ in wheat and mustard, respectively on soft agar while in case of pot experiment there was a delay in seed germination in presence of $2 \%$ mobil oil hydrocarbons. However, the seed germination percentage was better in presence of bacterial consortium over the control. Further, it was found that in case of wheat plant, consortium C3 was better at 


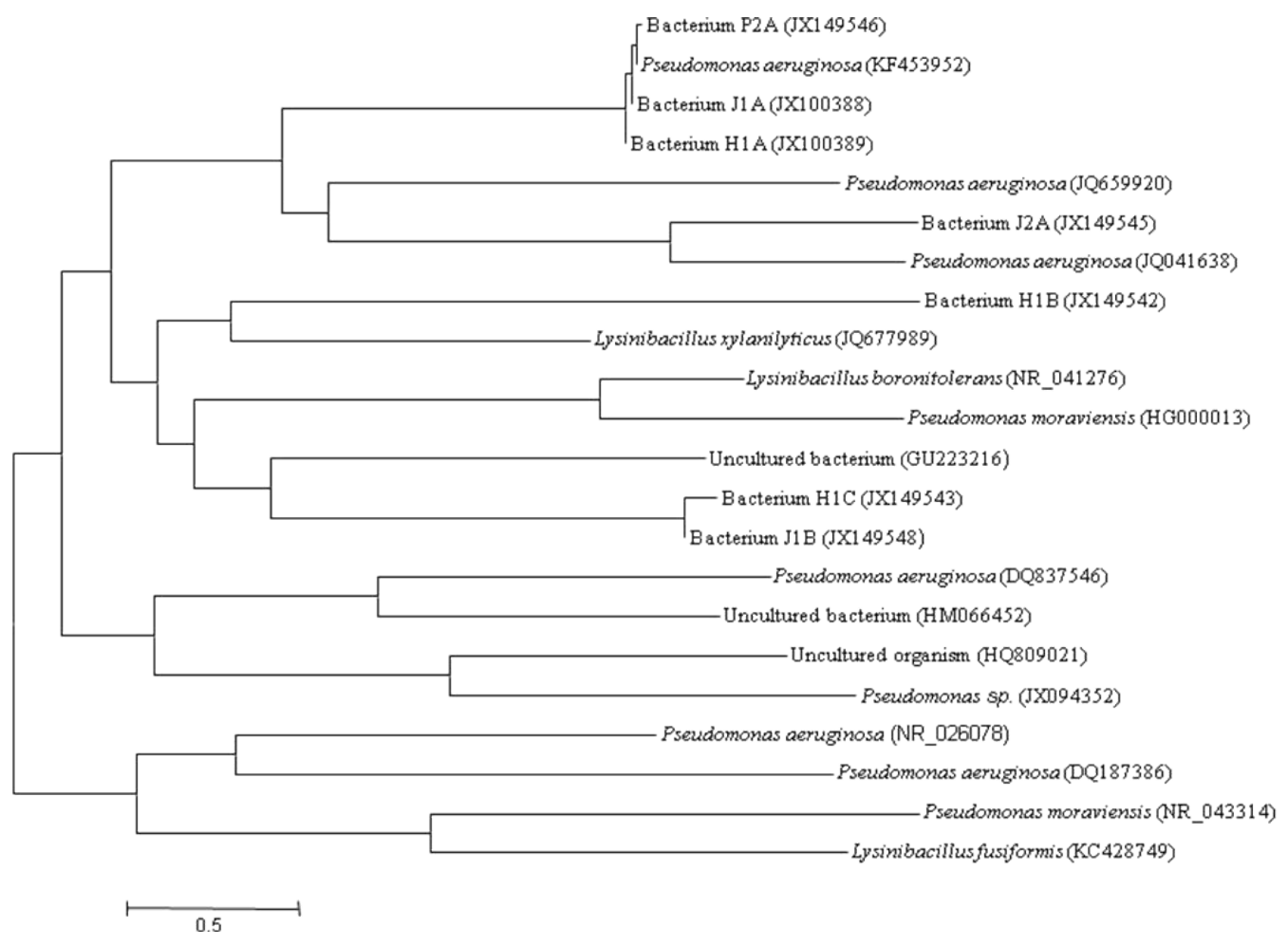

Figure 1: Phylogenetic tree: Relationship amongst test strains by neighbor joining method.

10 DAS while by 15 DAS, consortium C2 was found to be better in seed germination than the other two consortiums $\mathrm{C} 1$ and $\mathrm{C} 3$. While, in case of mustard plants, consortium C3 was better in seed germination over the other two consortiums at 10 and 15 days after sowing. Similar findings regarding delay in seed germination have been also reported by Okolo et al. [25].

Further, in case of plant growth parameters such as average plant height, the order for the effectiveness of the developed bacterial consortium in case of wheat plant was $\mathrm{C} 1>\mathrm{C} 3>\mathrm{C} 2, \mathrm{C} 3>\mathrm{C} 1>\mathrm{C} 2$ and $\mathrm{C} 3>\mathrm{C} 1>\mathrm{C} 2$ at a time interval of 30,60 and 90 Days After Sowing (DAS), respectively, while in case of mustard plants, it was $\mathrm{C} 1>\mathrm{C} 2>\mathrm{C} 3$, $\mathrm{C} 2>\mathrm{C} 1>\mathrm{C} 3$ and $\mathrm{C} 2>\mathrm{C} 1>\mathrm{C} 3$ in the same time interval, respectively. The chlorophyll content was found to be more in presence of consortium C3 and C2 for wheat and mustard plants, respectively at 45 days after sowing. Moreover, the average root weight, average stem weight with spikes and average seed weight was recorded more in case of consortium C3 as compared to other two consortium at 120 DAS in case of wheat plants. But, in case of mustard plants, consortium C1 was found more effective for average root weight and average seed weight whereas for average stem weight with pods, consortium C2 was found more effective as compared to other two consortiums.

All the plant growth parameters, in presence of consortia were found to be better compared to the control plants grown in absence of $2 \%$ mobil oil hydrocarbons. Similar findings have been also reported earlier by Akinola et al. [26] and Merkl et al. [27] while studying the effect of petro-hydrocarbons on plant growth parameters. In some of the parameters like seed germination and plant height, there was a delay in performance of the consortia and as the time passed, consortia performed better and even better than plants without mobil oil hydrocarbons.

\section{GC-MS analysis}

The GC-MS analysis showed that the compounds appearing in the control sample at 0 DAS in different retention time were mostly absent from both the samples after 120 days of treatment. It indicates that most of the compounds were degraded by the developed bacterial consortia and utilized as carbon and energy sources. Further, the peaks were characterized for the type of metabolite produced during the biodegradation of mobil oil hydrocarbons in wheat and mustard rhizospheric soil. In case of wheat with consortium C3, some new peaks were observed at Retention Time (RT) 24.354 and identified as 1,2-benzenedicarboxylic acid, dioctyl ester while in case of mustard with $\mathrm{C} 1$ consortium, two new peaks were observed at Retention Time (RT) 24.342 and 30.721, identified as1,2-Benzenedicarboxylic acid, mono (2-ethylhexyl) ester and 4a,7,7,10a-tetramethyl-dodecahydro-benzo[f] chromen-3-ol respectively (Figure 4). The average\% degradation of mobil oil (2\%) contaminated soil in C3M2W was $73.66 \%$ and in C1M2M was $75.80 \%$.

\section{Conclusion}

Hence, in this study, we concluded that the bacterial consortium C3 (J1A, J1B, H1C) and consortium C1 (H1A, H1B and H1C) were capable to enhance degradation of $2 \%$ mobil oil hydrocarbons in wheat (Triticum aestivum) and mustard rhizosphere, respectively. Moreover, consortium C3 degraded mobil oil hydrocarbons in wheat rhizosphere with an efficiency of $73.66 \%$ while consortium $\mathrm{C} 1$ degraded hydrocarbons with an efficiency of $75.80 \%$ in mustard rhizosphere in 150-180 days. Sathish Kumar et al. [28] also reported enhanced degradation of $1 \%$ crude oil by a mixed bacterial consortium consisting of Bacilllus, Corynebacterium, Pseudomonas HPS2 and BPS1 strains as compared to individual strains, however, the percentage degradation was only 
Citation: Kumar R, Bharagava RN, Kumar M, Singh SK, Govind K (2013) Enhanced Biodegradation of Mobil Oil Hydrocarbons by Biosurfactant Producing Bacterial Consortium in Wheat and Mustard Rhizosphere. J Pet Environ Biotechnol 4: 158. doi:10.4172/2157-7463.1000158
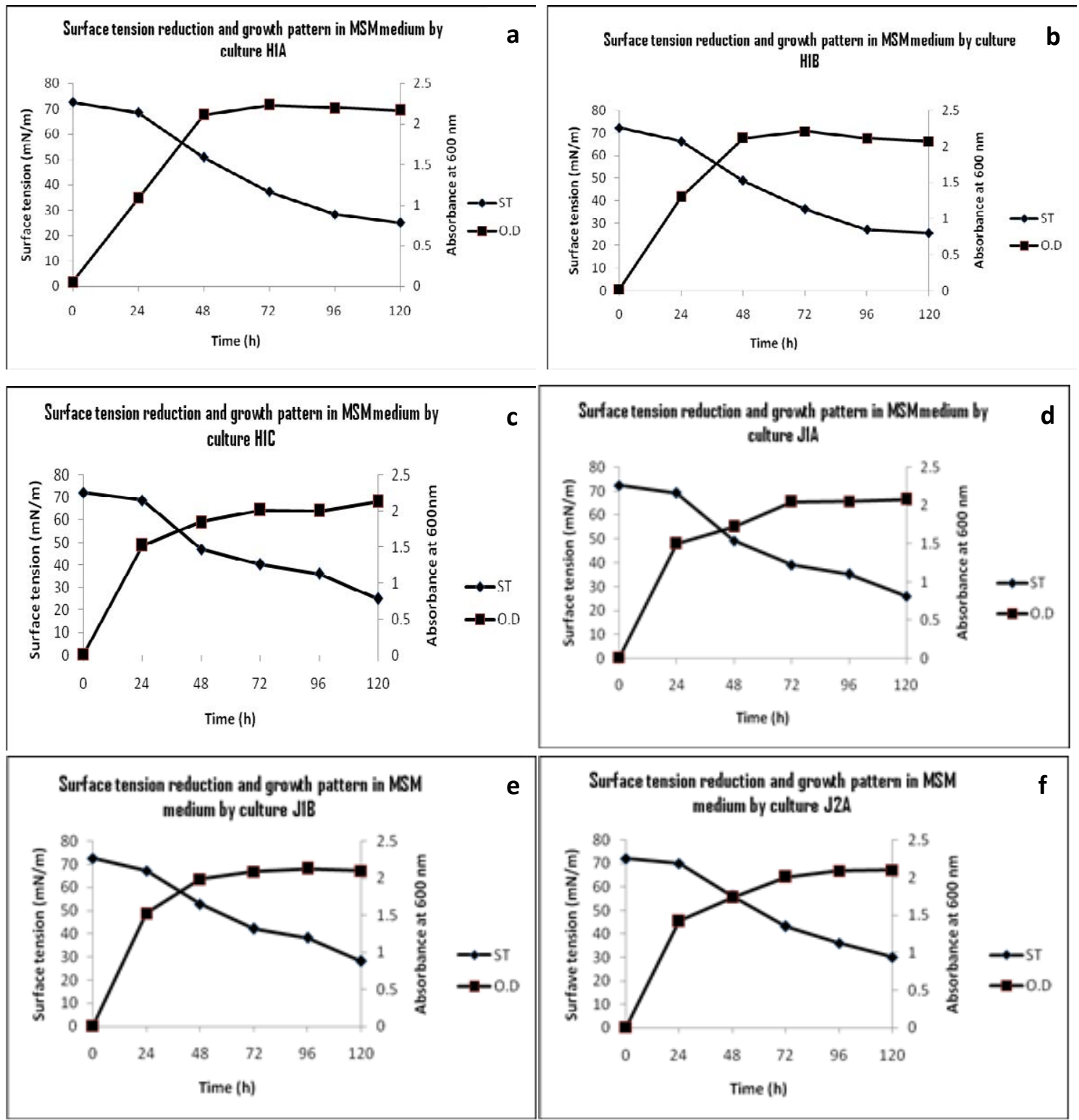

Surface tension reduction and growhh pattern in MSMmedium by $\quad$ g
culture P2A
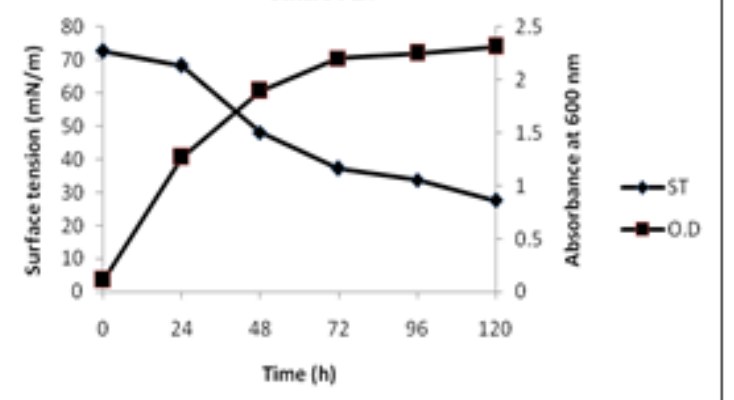

ST: Surface Tension

OD: Optical Density for Growth Measurement

Figure 2: Surface Tension reduction by crude biosurfactant produced by the isolates (a) H1A, (b) H1B, (c) H1C, (d) J1A, (e)J1B, (f) J2A, (g) P2A. 

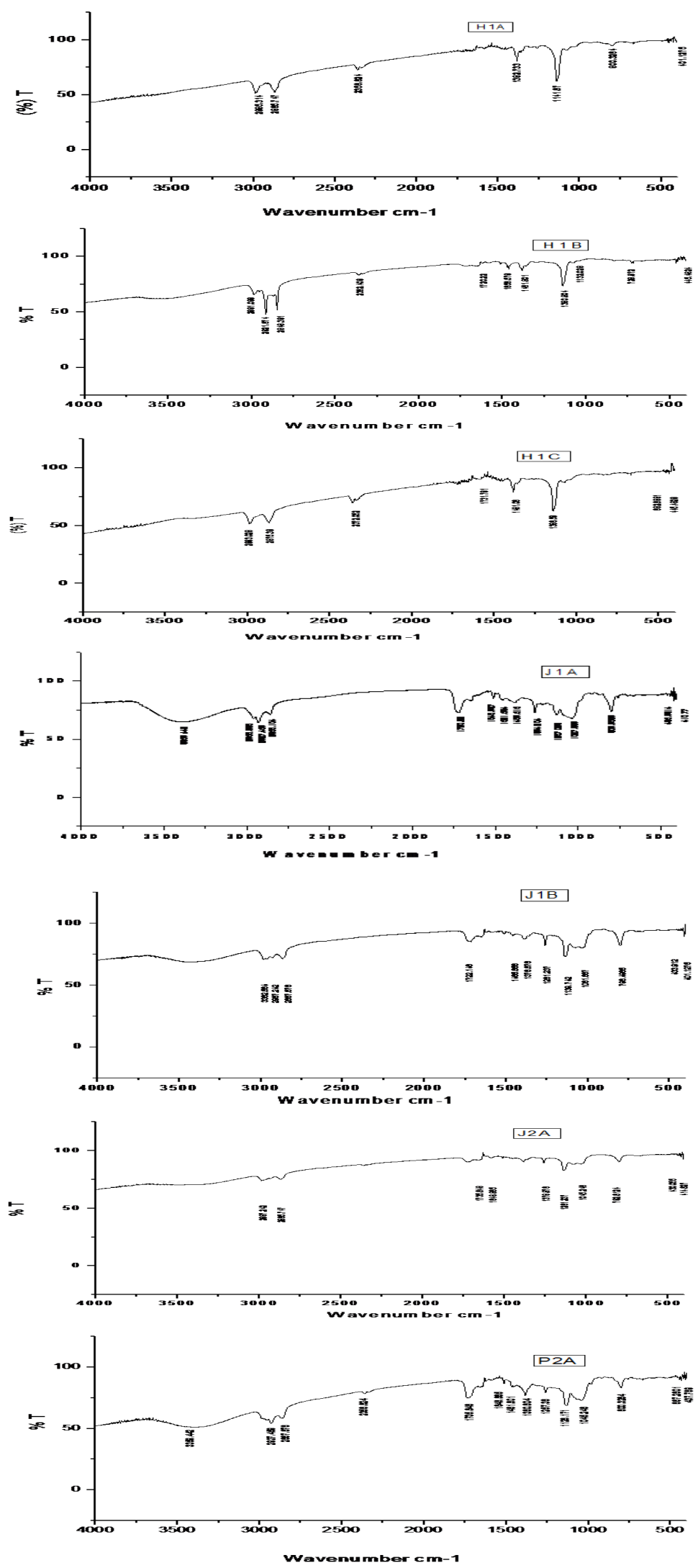

Figure 3: FTIR spectra of biosurfactant produced by various test strains in MSM media amended with dextrose carbon source. 
Citation: Kumar R, Bharagava RN, Kumar M, Singh SK, Govind K (2013) Enhanced Biodegradation of Mobil Oil Hydrocarbons by Biosurfactant Producing Bacterial Consortium in Wheat and Mustard Rhizosphere. J Pet Environ Biotechnol 4: 158. doi:10.4172/2157-7463.1000158

Comp. Name:1,2-benzenedicarboxylic acid, dioctyl ester

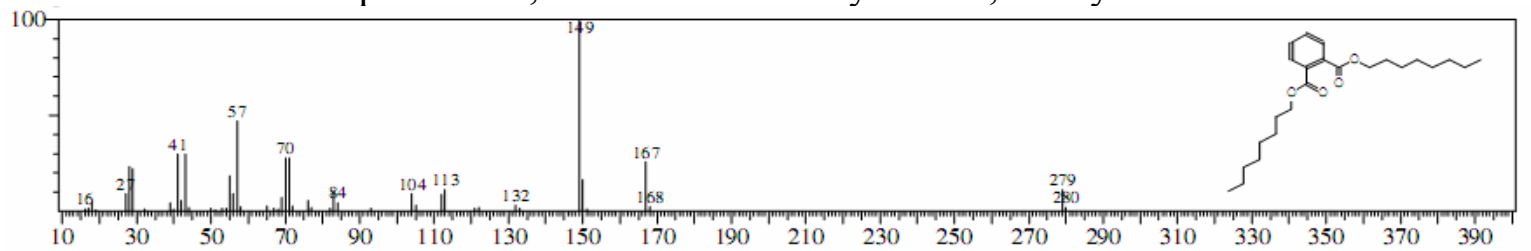

Comp. Name:1,2-Benzenedicarboxylic acid, mono(2-ethylhexyl) ester
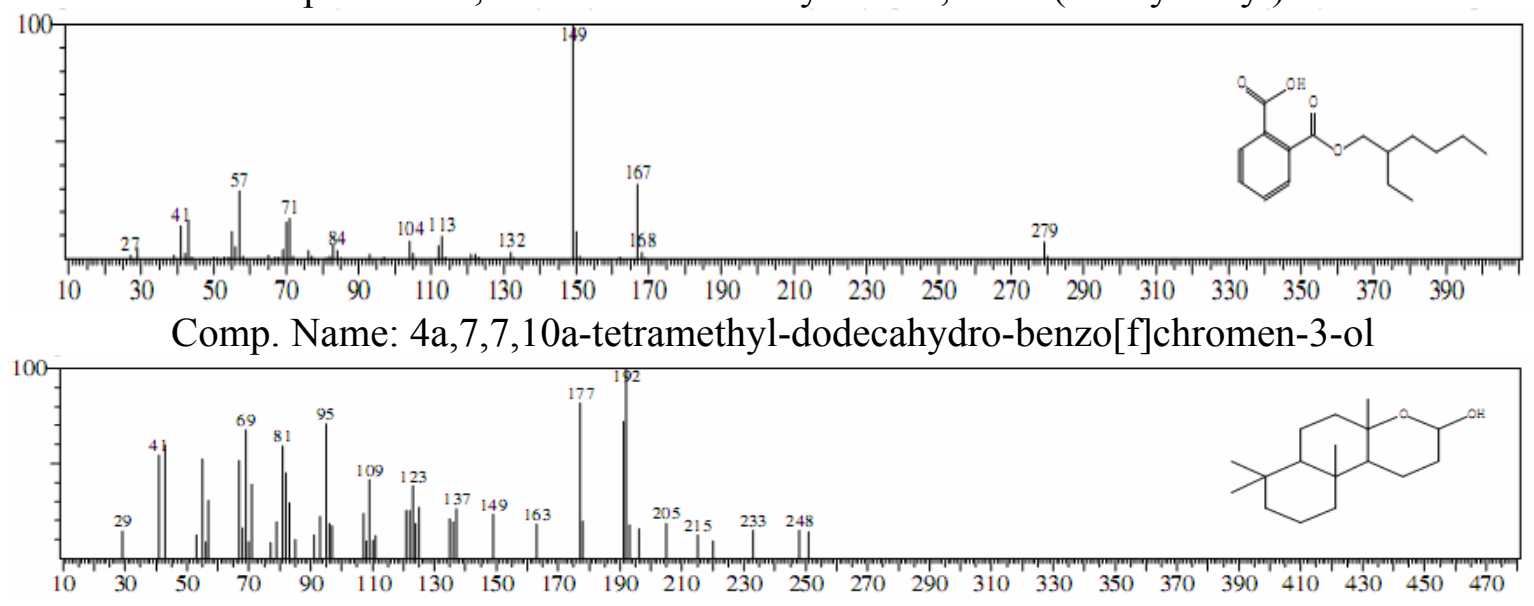

Figure 4: New peaks observed after degradation of $2 \%$ diesel hydrocarbons and identification of new compound in wheat rhizospheric soil (A) and mustard rhizospheric soil (B).

77\%. Tapis massa oil degradation by bacterial consortium from crude oil refinery ground water has also been reported [29]. The phthalate esters [1,2-benzenedicarboxylic acid and 1,2-Benzenedicarboxylic acid, mono (2-ethylhexyl) ester] formed during the degradation of mobil oil (Figure 4) can be used as plasticizer or for softening of PVC material as they are less toxic to mammalian health.

So, the consortium used in the present study besides biodegradation of mobil oil hydrocarbons (bioremediation) from contaminated sites, can also be used in the synthesis of phthalate esters for industrial applications.

\section{Acknowledgment}

The author of this paper wishes to acknowledge Indian National Science Academy, New Delhi for providing financial assistance to carry out this work.

\section{References}

1. Pacwa-PÅ,ociniczak M, PÅ,aza GA, Piotrowska-Seget Z, Cameotra SS (2011) Environmental applications of biosurfactants: recent advances. Int J Mol Sci 12: $633-654$

2. Glick BR (2003) Phytoremediation: synergistic use of plants and bacteria to clean up the environment. Biotechnol Adv 21: 383-393.

3. Glick BR (2010) Using soil bacteria to facilitate phytoremediation. Biotechnol Adv 28: 367-374

4. Al-Mailem DM, Sorkhoh NA, Al-Awadhi H, Eliyas M, Radwan SS (2010) Biodegradation of crude oil and pure hydrocarbons by extreme halophilic archaea from hypersaline coasts of the Arabian Gulf. Extremophiles 14: 321 328.

5. Margesin R, Schinner F (2001) Biodegradation and bioremediation of hydrocarbons in extreme environments. Appl Microbiol Biotechnol 56: 650-663.
6. Nievas ML, Commendatore MG, Esteves JL, Bucalá V (2008) Biodegradation pattern of hydrocarbons from a fuel oil-type complex residue by an emulsifierproducing microbial consortium. J Hazard Mater 154: 96-104.

7. Mulligan CN, Gibbs BF (2004) Types, production and applications of biosurfactants. Proc Indian Nat Sc Acad B70 1: 31-55.

8. Urum K, Pekdemir T (2004) Evaluation of biosurfactants for crude oil contaminated soil washing. Chemosphere 57: 1139-1150.

9. Lyman WJ, Reidy PJ, Levy B (1992) Mobility and degradation of organic contaminants in subsurface environments. CRC Press, USA.

10. Franzetti A, Gandolfi I, Bestetti G, Smyth TJP, Banat IM (2010) Production and applications of trehalose lipid biosurfactants. Eur J Lipid Sci Tech 112: 617-627.

11. Bento FM, Camargo FA, Okeke BC, Frankenberger WT (2005) Comparative bioremediation of soils contaminated with diesel oil by natural attenuation biostimulation and bioaugmentation. Bioresour Technol 96: 1049-1055.

12. Glick BR (2012) Plant Growth-Promoting Bacteria: Mechanisms and Applications. Scientifica.

13. Lugtenberg BJJ, de Weger LA, Bennett JW (1991) Microbial stimulation of plant growth and protection from disease. Curr Opin Biotech 2: 457-464.

14. van Loon LC, Bakker PA, Pieterse CM (1998) Systemic resistance induced by rhizosphere bacteria. Annu Rev Phytopathol 36: 453-483.

15. Meyer JM (2000) Pyoverdines: pigments, siderophores and potential taxonomic markers of fluorescent Pseudomonas species. Arch Microbiol 174: 135-142.

16. Barrow GI, Feltham RKA (1993) Cowan and Steel's manual for the identification of medical bacteria, 3rd edition. Cambridge University Press, Cambridge, USA.

17. Schwyn B, Neilands JB (1987) Universal chemical assay for the detection and determination of siderophores. Anal Biochem 160: 47-56.

18. Karnwal A (2009) Production of Indole Acetic Acid by Fluorescent Pseudomonas In The Presence Of L-Tryptophan and Rice Root Exudates. Journal of Plant Pathology 91: 61-63. 
Citation: Kumar R, Bharagava RN, Kumar M, Singh SK, Govind K (2013) Enhanced Biodegradation of Mobil Oil Hydrocarbons by Biosurfactant Producing Bacterial Consortium in Wheat and Mustard Rhizosphere. J Pet Environ Biotechnol 4: 158. doi:10.4172/2157-7463.1000158

Page 8 of 8

19. Voisard C, Keel C, Haas D, Dèfago G (1989) Cyanide production by Pseudomonas fluorescens helps suppress black root rot of tobacco under gnotobiotic conditions. EMBO J 8: 351-358.

20. Nautiyal CS (1999) An efficient microbiological growth medium for screening phosphate solubilizing microorganisms. FEMS Microbiol Lett 170: 265-270.

21. Zajic JE, Seffens W, Panchal C (1983) Biosurfactants. CRC Cr Rev Biotechn 1: 87-107.

22. Cooper DG, Goldenberg BG (1987) Surface-active agents from two bacillus species. Appl Environ Microbiol 53: 224-229.

23. Meyer JM, Geoffroy VA, Baysse C, Cornelis P, Barelmann I, et al. (2002) Siderophore-mediated iron uptake in fluorescent Pseudomonas: characterization of the pyoverdine-receptor binding site of three cross-reacting pyoverdines. Arch Biochem Biophys 397: 179-183.

24. Patten CL, Glick BR (1996) Bacterial biosynthesis of indole-3-acetic acid. Can J Microbiol 42: 207-220.
25. Okolo JC, Amadi EN, Odu CTI (2005) Effects of soil treatments containing poultry manure on crude oil degradation in a sandy loam soil. Applied Ecology And Environmental Research 3: 47-53.

26. Akinola MO, Udo AS, Okwok N (2004) Effect of crude oil (Bonny Light) on germination, early seedling growth and pigment content in maize (Zea mays L.). Journal of Science Technology and Environment 4: 6-9.

27. Merkl N, Schultze-Kraft R, Infante C (2004) Phytoremediation in the TropicsThe Effect of Crude Oil on the Growth of Tropical Plants. Bioremediation Journal 8: 177-184.

28. Sathish-Kumar M, Binupriya AR, Baik SH, Yun SE (2008) Biodegradation of Crude Oil by Individual Bacterial Strains and a Mixed Bacterial Consortium Isolated from Hydrocarbon Contaminated Areas. CLEAN-Soil, Air, Water 36 92-96.

29. Hamzah A, Phan CW, Bakar NFA, Wong KK (2013) Biodegradation of Crude Oil by Constructed Bacterial Consortia and the Constituent Single Bacteria Isolated From Malaysia. Bioremediation Journal 17: 1-10. 